\title{
PIRO scoreによる臨床研究が敗血症治療の活路を拓く？
}

要約：現在の集中治療医学の最重要課題の一つが, 敗血症の克服である。しかし, これまで の多くの臨床研究の中で明確な有効性を証明できた治療戦略は少なく, 対象患者の選定基準 が原因の一つとされる。感染が原因で全身性炎症反応症候群 (systemic inflammatory response syndrome, SIRS) 状態にあれば, 敗血症と定義される。しかし, SIRSの診断基準 は特異性にそしく患者の重症度や病態を反映していない。そこで, 腫瘍学の世界の TNM分類 にならい提唱されたのがPIRO scoreである。Pはpredisposition (背景, 素質), Iはinsult/ infection (侵襲 / 感染), Rはresponse (反応), O は organ dysfunction(臟器障害)を意味し, 各々のカテゴリーをスコア化して敗血症の進行度を分類しょうとするものである。各カテゴ リーを構成する内容は, 重症敗血症, 市中肺炎, 院内肺炎などでモデルが提唱され，実際の 患者の予後を良く反映することが証明されつつある。このPIRO scoreにより重症度を均質化 した臨床研究が期待されている。

Key words: (1) severe sepsis, (2) septic shock, (3) systemic inflammatory response syndrome (SIRS), (4) PIRO score, (5) TNM classification

\section{I .はじめに}

今日の集中治療医学の最重要課題の一つは, 敗血症 の克服と言って良いと思われる。しかし, 幾多の臨床 研究がなされながら, 普遍的な有効性を示すことので きた治療方法は非常に稀である。比較的エビデンスの 質が高いとされる多施設, 二重盲検, 無作為比較試験 (randomized controlled trial, RCT) をもってしても, 同一治療方法でしばしば結果が異なり, 対象となる患 者の選定方法に問題があるとの指摘がある1)。本稿で は敗血症の定義にさかのぼり, PIRO score誕生の背景 から, 今後の期待される展開について述べる。

\section{II．敗血症の定義について}

2008年に改訂第2版のSurviving Sepsis Campaign guideline ${ }^{2)}$ が公表された。GRADE systemを用い,ガ イドラインの文言を推奨度の強さとエビデンスの質か ら重み付けしている。その中で, grade 1Aとして質
の高いエビデンスに裏付けされ強く推奨される項目 は,わずかに6項目に過ぎない。

その 6 項目のうちの一つとしてステロイドに関する 記載がある。すなわち,「ハイドロコルチゾン 300 $\mathrm{mg} / \mathrm{day}$ 相当以上のステロイドを, 重症敗血症, 敗血 症性ショックの治療として使用してはならない」とい う項目である。この項目のエビデンスとして取り上げ られているのが, 1987年の The New England Journal of Medicineの317巻に前後して揭載された二つの大 規模な $\mathrm{RCT}{ }^{3), 4)}$ である。当時, 敗血症性ショックの治 療としてステロイドのパルス療法が広く行われていた が, この二つの RCTでは大量ステロイド療法が敗血 症性ショックの予後を改善しないばかりか, 二次感染 からの回復はプラセボ群の方が有意に高率であったこ と, ステロイド使用群で有意に二次感染による死亡が 多かったこと ${ }^{3)}$, 腎機能障害のある患者ではステロイ ド使用群で死亡率が有意に高かったことなどが報告さ れた4)。この報告では, 患者の登録基準として, 感染 症の臨床的証拠, 体温異常, 頻脈, 頻呼吸, 臟器灌流障 害の兆候などを採用していた。この著者こそがRoger 
C. Boneであった。当時の呼吸器疾患, 敗血症の第一 人者であるBoneのもとでは, 他にも数多くの敗血症 治療に関する臨床研究がなされたが, 有意な結果が得 られた治療方法はなかった ${ }^{5177 。 ~}$

そこで, 敗血症と臟器障害の定義を見直すカンファ ランスが行われ, 初めて全身性炎症反応症候群 (systemic inflammatory response syndrome, SIRS)

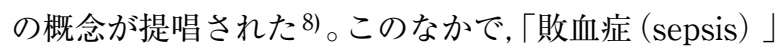
とは, 感染に起因するSIRS状態と定義された。この カンファランスでは, 敗血症に関連するその他の用語 に関しても以下のように定義された。

「感染 (infection)」とは, 本来無菌の組織に微生物 が侵入して炎症反応を惹起している状態。

「菌血症 (bacteremia)」とは, 菌が血中に生存して いる状態。

「重症敗血症 (severe sepsis) 」とは, 臟器障害をと もなう敗血症で, 臟器障害とは低灌流, 低血圧, 乳酸 アシドーシス，乏尿，意識障害などを指す。

「敗血症性ショック (septic shock)」とは, 適切な輸 液負荷にもかかわらず持続する低血圧, 低灌流状態を 指す。

Boneは, こうした広い定義を提唱することで, 臨床 上, 早期の診断, 治療に結びつくことを期待し，また 臨床研究を標準化するうえでも貢献するだろうと予想 した。ただ、リスクの層別化 (stratification)をはかる ためには,さらなる研究が必要なことも明記している。

\section{III. 活性化プロテインCの有効性は, 研究ごとに異なる}

2001年, 活性化プロテインCを重症敗血症患者に使 用すると, 28 日後の生存率が $75.3 \%$ とプラセボ群の $69.2 \%$ と比較して有意 $(P=0.006)$ に改善すると報告 された (PROWESS study) ${ }^{9)}$ 。この報告は, 敗血症に 使用された薬物で初めて, 患者の予後を改善できたと する画期的なものであった。研究デザインは, 多施設, 二重盲検, $\mathrm{RCT}$ で, 対象患者も 1,690 名と十分な標本 量であった。活性化プロテインCは, 感染による炎症 反応や血栓形成を抑制する一方, プラスミノーゲン活 性化抑制因子を不活化することで線溶反応を維持して 末梢循環を維持するなどの作用がある。しかし，一方 では出血性の合併症も懸念される。本研究では, 活性 化プロテインCを使用した群の出血性合併症が $3.5 \%$ だったのに対して,プラセボ群では $2.0 \%$ と有意では ない $(P=0.06)$ ものの若干多かった。その後, Elyら はPROWESS studyのサブグループ解析を行い, 重症 度と活性化プロテインCの効果との関連を調べた ${ }^{10) 。 ~}$
その結果, 患者の予測死亡率が高い重症患者ほど, 活 性化プロテインCを使用すると死亡率が改善すること が判明し, どうやら患者の重症度によって効果が異な ることが示唆された。

こうした事実から，活性化プロテインCを認可した 米国食品医薬品局は, 死亡リスクの低い重症敗血症患 者にも使用可能か調查を求めた。その結果を報告した

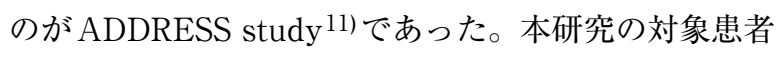
は, Acute Physiology and Chronic Health Evaluation (APACHE) II score < 25ないし単一臟器障害の重症 敗血症患者に限られ, 介入方法はPROWESS study と 同様, 活性化プロテインC 群は $24 \mu \mathrm{g} / \mathrm{kg} / \mathrm{hr} \times 4$ 日間 で投与され, プラセボ群との比較が行われた。その結 果は, 28 日後の予後に有意差を認めないばかりか, 薬 剂投与中もその後の経過観察中も, 活性化プロテイン C 群に重篤な出血性合併症が有意に多い $(3.9 \% \mathrm{vs}$ $2.2 \%, P=0.01)$ 結果となった。

一方, 先のPROWESS studyに参加していた VincentはBernardらとともに, 重症敗血症患者に早 期に活性化プロテインC を使用すると効果的だとする 非比較, 非二重盲検, 多施設試験を報告した (ENHANCE study) 12)。対象は, 感染を合併し, SIRS 基準を 3 項目以上満たし, 一臟器以上の不全臟器があ る患者2,375名で, 介入はPROWESS study と同様で あった。その結果, 生存率はPEOWESS studyの活性 化プロテインC群と全く同一の曲線を示した。また, 活性化プロテインCを 24 時間以内に使用した群は, 24 時間以降に使用した群と比較すると有意に生存率 が高かった。

前向きの RCTではないが, 活性化プロテインCを 使用した患者の予後を後ろ向きに調べたCanadian studyでは, 活性化プロテインC群での死亡率 $45 \%$, 重篤な出血性合併症は $10 \%$ と, それまでのRCTと 比較して高い数值であった ${ }^{13)}$ 。Canadian studyの対 象患者の臓器不全数は 3.4 たたのに対して, PROWESS studyでは2.4, ENHANCE studyでは2.7 と少なく, 結果としての活性化プロテインC群での死 亡率もPROWESSが $24.7 \%$, ENHANCE studyが 25.3\%なのに対してCanadian studyでは $45.2 \% に$ に達し た。出血性合併症に関しても, 当初のPROWESS studyの1〜2.4\%から Canadian studyでは 7.3\%にま で増加した。2001年に初めて活性化プロテインCの RCTの結果が報告されて以来, 経時的にその有効性は

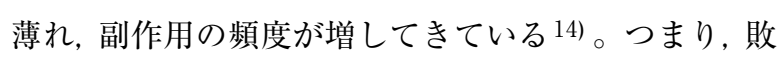
血症の診断基準を遵守して患者登録を行っても, 各 RCTの対象患者には不均一性が存在し, 定まった結果 
を生み出せないという問題が明らかになってきた。

\section{IV．SIRSから層別化システムへ}

確かに, SIRSは敗血症の定義を明確にしたが, 決し て敗血症の病態や重症度を反映しているわけではな い。感度が高すぎて, ICU患者の相当数がSIRS 基準 に合致してしまうし，一般病棟の患者でもかなりの患 者が該当してしまう。病態の異なる患者を束ねてしま うことにもなりかねない。外傷患者, 術後患者, 肺塞栓, 心筋梗塞のいずれもSIRS基準に合致してしまい, 病 態生理を反映していない。すなわち, 感度を上げるこ とによって, 特異度を下げる結果となっている1)。

先に敗血症の定義づけを行った1991年のコンセン サスカンファランスの 10 年後に, その定義の見直し が行われた15)。その中でも, 敗血症に関する諸定義 は基本的にBoneらが示した定義と同一のもので良し とされた。また, 敗血症の診断基準として, 全身症状, 炎症反応, 血行動態, 臟器障害, 組織灌流異常などに 関して,より具体的な兆候が記載された。そして最後 に, 敗血症に打いても層別化システムが必要なことが 強調された。

敗血症, 重症敗血症, 敗血症性ショックについて各々 の定義はあっても, それが敗血症患者の正確な病態や 重症度を反映しているわけではない。患者のリスク背 景と, 治療に対する反応を層別化することによって, 臨床的に有用な層別化システムを確立することが可能 になることが期待される。臨床では, 最も進化した層 別化システムがTNM分類で，これをモデルにするの が良いと提案された。これは，2000年にカナダのトロ ントで行われた第 5 回トロント敗血症円卓会議で, カ ナダの外科医であるJohn C MarshallがIRO層別化シ ステムを提唱したのが発端であった。Marshallは, oncologistが, がんを T (tumor, 腫瘍), N (node, リン パ節） $\mathrm{M}$ (meta-stasis, 遠隔転移) と分けて stagingし たように，敗血症も定義域別にstagingするのが良い のではと考え, insult (侵襲), response (反応), organ dysfunction (臓器障害)の各々をstagingするIRO systemを提案した16)。

TNM分類は, 1943年から 1952年にかけてPierre Denoixが開発したものである。1953年に国際対がん 連合の「腫瘍の命名法抒よび統計委員会」がTNM 分類 を採用し, 1954年にはすべての臟器のがんにこの分 類法が拡大された。その後, 一部の団体が勝手に分類 法を改変したりすることがあり，1982年にはTNM分 類の標準化, 統一化が計られるようになった ${ }^{17) 。 ~}$
Marshallが当初提案したIRO systemは, その後の カンファランスでPIRO system と改められ定義づけ された (Table 1) 15)。Pは, predisposition (素因)を意 味し, 臨床所見としては年齢, 合併症〔糖尿病, 肝硬 変, 腎不全, 心不全, 慢性閉塞性肺疾患 (chronic obstructive pulmonary disease, COPD)など], 性別, 人種, 宗教, 文化的背景, ステロイドやその他の免疫 抑制薬の使用歴などが該当する ${ }^{18)}$ 。検査によって判 明する素因としては, インターロイキン (interleukin, IL) -1 receptor antagonist遺伝子の多型性が指摘され ているほか, 腫場壊死因子 (tumor necrosis factor, TNF）a遺伝子やToll様受容体 (Toll-like receptor, TLR）1遺伝子の多型性なども, 敗血症の予後を左右 する素因の可能性がある。実際, 欧州集中治療医学会 では, 敗血症の予後が, 遺伝的背景によっていかに影 響されるかを調べるGenOSept trial（Genetics Of Sepsis \& Septic shock）を展開してデータを蓄積中で ある。

Iはinsult/infection (侵襲/感染)を示している19)。 臨床的には, 感染の病巣がどこなのか (肺, 腹膜, 尿路, 血流路など), 院内感染か市中感染か, 発症の夕イミン グがどうなのか，などが分類項目候補となる。

同じ敗血症性ショックでも, 早期発症と遅発性では 内容が異なる。Roman-Marchantらは, ICU入室 24 時 間以内に発症した敗血症性ショック 41 名と, 入室 24 時間以降に発症した敗血症性ショック 24 名を吟味し た20)。その結果, 早期発症群では起炎菌として Streptococcus pneumoniaeが10名に認められたのに対 して, 遅発性群では一例もS. pneumoniae は認められ なかった。逆に, 遅発性群でPseudomonas aeruginosa が5名に認められたのに対して, 早期発症群では 1 例 もなかった。早期発症群では APACHE II scoreが 26 \pm 6 と遅発性群の $20 \pm 6$ より有意に高い $(P=0.002)$ ものの, ICUの滞在期間は 75 日対 477 日と遅発性群の 方が有意に長期化した $(P<0.001)$ 。侵襲 $/$ 感染の検 査上の分類項目としては, 起炎菌, 毒性, 感受性など による分類が考えられる。感染巣と起炎菌は，いずれ も重要な予後決定因子で, 相互に影響し合うことが大 規模な後ろ向き研究で示されている。

Cohen らは, 過去 30 年間の 510 編の論文を系統立て て調查し, 55,854感染例の解析を行った ${ }^{21)}$ 。死亡率 とデータの質に関してGRADE systemを適用しなが ら解析した結果, 血流感染は死亡率が高いことが良質 なデータで裏付けられた。髄膜炎は, 質の高いデー夕 により死亡率が高いことが証明されたが, 起炎菌が Neisseria meningitisの場合には死亡率が 6 〜 15\%の 
Table 1 The PIRO system for staging sepsis ${ }^{15)}$ reprinted with permission

\begin{tabular}{|c|c|c|c|}
\hline Domain & Present & Future & Rationale \\
\hline Predisposition & $\begin{array}{l}\text { Premorbid illness with } \\
\text { reduced probability of } \\
\text { short term survival. } \\
\text { Cultural or religious } \\
\text { beliefs, age, sex. }\end{array}$ & $\begin{array}{l}\text { Genetic polymorphisms in } \\
\text { components of inflammatory } \\
\text { response (e.g., TLR, TNF, IL-1, } \\
\text { CD14); enhanced understand- } \\
\text { ing of specific interactions } \\
\text { between pathogens and host } \\
\text { diseases. }\end{array}$ & $\begin{array}{l}\text { In the present, premorbid factors impact } \\
\text { on the potential attributable morbidity and } \\
\text { mortality of an acute insult; deleterious } \\
\text { consequences of insult heavily dependent } \\
\text { on genetic predisposition (future). }\end{array}$ \\
\hline $\begin{array}{l}\text { Insult/ } \\
\text { infection }\end{array}$ & $\begin{array}{l}\text { Culture and sensitivity } \\
\text { of infecting pathogens; } \\
\text { detection of disease } \\
\text { amenable to source } \\
\text { control. }\end{array}$ & $\begin{array}{l}\text { Assay of microbial products } \\
\text { (LPS, mannan, bacterial DNA); } \\
\text { gene transcript profiles. }\end{array}$ & $\begin{array}{l}\text { Specific therapies directed against inciting } \\
\text { insult require demonstration and charac- } \\
\text { terization of that insult. }\end{array}$ \\
\hline Response & $\begin{array}{l}\text { SIRS, other signs of } \\
\text { sepsis, shock, CRP. }\end{array}$ & $\begin{array}{l}\text { Nonspecific markers of } \\
\text { activated inflammation (e.g., } \\
\text { PCT or IL-6) or impaired host } \\
\text { responsiveness (e.g., HLA-DR); } \\
\text { specific detection of target of } \\
\text { therapy (e.g., protein C, TNF, } \\
\text { PAF). }\end{array}$ & $\begin{array}{l}\text { Both mortality risk and potential to } \\
\text { respond to therapy vary with nonspecific } \\
\text { measures of disease severity (e.g., shock); } \\
\text { specific mediator-targeted therapy is } \\
\text { predicated on presence and activity of } \\
\text { mediator. }\end{array}$ \\
\hline $\begin{array}{l}\text { Organ } \\
\text { dysfunction }\end{array}$ & $\begin{array}{l}\text { Organ dysfunction as } \\
\text { number of failing } \\
\text { organs or composite } \\
\text { score (e.g., MODS, } \\
\text { SOFA, LODS, PEMOD, } \\
\text { PELOD). }\end{array}$ & $\begin{array}{l}\text { Dynamic measures of cellular } \\
\text { response to insult-apoptosis, } \\
\text { cytopathic hypoxia, cell stress. }\end{array}$ & $\begin{array}{l}\text { Response to preemptive therapy (e.g., } \\
\text { targeting microorganism or early } \\
\text { mediator) not possible if damage already } \\
\text { present; therapies targeting the injurious } \\
\text { cellular process require that it be present. }\end{array}$ \\
\hline
\end{tabular}

範囲にとどまることが示された。また肺炎の起炎菌と しては圧倒的にS. pneumoniaeが多いが, 死亡率に関 しては6〜15\%と低い。一方, Klebsiella speciesや Pseudomonas aeruginosa, Acinetobactor species, Staphylococcus speciesなどによる肺炎は, 数は少ない ものの死亡率が $30 \%$ 以上と対照的である。尿路感染 は, いずれの起炎菌でも死亡率が $5 \%$ 以下であること が示されている。

Rはresponse (反応) を意味しており, 臨床症状とし て体温, 脈拍, 血圧, 心拍出量, SIRSなどが層別化の

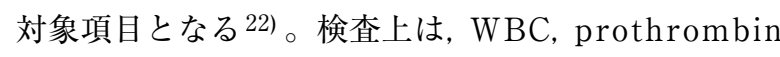
time, activated partial thromboplastin time (APTT), 動脈血ガス分析, 乳酸值, CRP, procalcitonin, IL-6, 凝固系, 副腎機能などのバイオマーカーが評価対象と なる。

Oはorgan dysfunction(臓器障害) の程度を表
す23)。臨床的には, 血圧, 尿量, 意識レベルなど, 敗 血症にともなう灌流障害からくる症状が層別化される ことになる。検査のうえでは, $\mathrm{P} / \mathrm{F}$ 比, 血清クレアチ ニン, 血清ビリルビン, 血小板数などが臓器障害を反 映すると考えられる。また, 現在までにいくつかの蔵 器障害スコアが使用されているので, それを流用する 方法もある。つまり, multiple organ dysfunction score (MODS) ${ }^{24)}$, Sequential Organ Failure Assessment (SOFA) score ${ }^{25) \sim 27)}$, Pediatric Multiple Organ Dysfunction (PEMOD) score ${ }^{28)}$, pediatric logistic organ dysfunction (PELOD) score 29 )などを使 用して臓器障害の評価とすることも可能と考えられ る。 


\section{PIRO scoreは, 予後予測に優れる}

すでに, いくつかの感染症がPIRO scoreによって 評価されている。Relloらは, ICUの市中肺炎患者の重 症度評価システムとしてPIROをあてはめ, APACHE II score や American Thoracic Society (ATS) 基準と 比較した (Table 2) ${ }^{30)}$ 。スペインの33のICUに入室 した市中肺炎の成人患者529名を対象に, PIROにも とづいて重症度をスコア化した。その結果, APCHE II scoreでは必ずしもスコアと死亡率が比例関係にな かったものが, PIRO scoreでは, 值が上昇するにつれ て死亡率が増加し, 予後を良く反映した。PIRO score, APACHE II score, ATS の重症度スコアの3 者 を receiver operating characteristic (ROC) 曲線下面 積で比較すると, PIRO score 0.88 [95\% confidence interval $(\mathrm{CI}): 0.83 \sim 0.90$ ], APACHE II score 0.75 (同, $0.70 \sim 0.80$ ), ATS 0.80 (同, $0.77 \sim 0.84$ ) であり, PIRO scoreがもっとも予後予測に優れていた。

呼吸器関連肺炎 (ventilator associated pneumonia, VAP)に関しても，PIROによる予後予測スコア化が 試みられている。Lisboaらは, 3つの多目的ICUの VAP患者441名を対象に, 多変量ロジステック解析か ら ICU死亡率に関係する因子を同定し，その結果を PIROの4つの定義域にあてはめて, 層別化を行った (Table 2) 31)。多変量ロジステック解析の結果, 有意 と判定された合併症の有無, 菌血症の有無, 収縮期血 圧 $<90 \mathrm{mmHg}$ か否か, acute respiratory distress syndrome (ARDS) の有無の4点をそれぞれpredisposition, infection, response, organ dysfunctionとして 1 点づつ付与し, 最低 0 , 最高 4 点の PIRO score とした。 ここで言う合併症とはCOPD, 免疫不全, 慢性心不全, 慢性肝不全, 慢性腎不全を指す。responseの血圧に関 しては収縮期血圧 $<90 \mathrm{mmHg}$ もしくは㫒圧薬の必要 性とした。その結果, VAPのPIRO scoreが 0 〜点ま で増加するにつれて, 死亡率が比例して上昇し $(P<$ 0.001), APACHE II scoreのROC曲線下面積が0.53 なのに対してVAP PIRO scoreの曲線下面積は 0.81 と 高く, $95 \%$ CIも $0.77 〜 0.85$ と優れた数值を示した。

Morenoらは, PIRO scoreが敗血症の死亡率予測に 使えるかを大規模な多施設, 多国間のデータベースを 使用して後ろ向きに観察した32)。使用したデータベー スは, simplified acute physiology score (SAPS) $3^{33), 34)}$ の作成に使用したもので, 2,628 名の感染症患者で 48 時間以上ICUに滞在した症例を使用した。本研究で は, PIROの4項目のうち, R : responseと O : organ dysfunctionとを一つのカテゴリーとして P, I, Rに関 する層別化をした。Predispositionとして, 年齢, どこ からの入室か, 合併症, 入院歴, 入室理由, infection と して, 感染の獲得場所, 感染の広がり, 感染巣, 起炎菌 を, そして response/organ function として, 機能障害, 機能不全の臟器をスコア化した。その結果, 予後予測 に関するROC曲線下面積はSAPS 3 が 0.735 (95\% CI : 0.716〜0.754) だったのに対してPIROでは 0.772 (95\% CI : 0.754 0.790) と, より感度, 特異度に優れ た成績であった。

Morenoらの研究が, 感染ないし敗血症患者を対象 としていたのに対し, Rubulottaらは, 重症敗血症で PIRO score を検討した ${ }^{35)}$ 。彼らは, 重症敗血症患者 の世界的なデータベース二つを使用して後ろ向きに, PIRO scoreによる新しい重症敗血症の staging model を構築し, 各カテゴリー内で死亡率リスクを層別化し た。使用したデータベースは, PROWESS study 9)の プラセボ群とPROGRESS study 36)で, 各々840例, 10,610例が対象となっている。PROWESS studyから 抽出したPIROに関与すると思われる変数は, 非常に 多岐にわたり, 年齢, 性別, 民族的背景, 頻脈, 頻呼吸, 白血球増多, 白血球減少, 体温異常, SIRS基準を満た す数, 証明された感染, 感染巣, 感染の型, APACHE II score, 臟器障害の数, 昇圧薬の必要性, うっ血性心 不全, 慢性腎不全, 慢性肝疾患, 糖尿病, 人工呼吸, 慢 性肺疾患, 意識低下, 活動性のがん, 術後早期などの 要素がリストアップされた。

これらのうち, 例えば背景因子を予後の観点から多 変量ロジステック解析を行ったところ, 年齢, 慢性肝 疾患の有無, うっ血性心不全の有無などが予後に影響 していた。そこで, それらの組み合わせにより, predispositionをP0〜P4まで5段階に層別化した。同 様にinsult/infectionをI0〜I4まで, responseはR0 と R1へ, organ dysfunctionは O0〜O4まで層別化し, 最低 0 点, 最高 13 点となるようにstaging modelを作 成した (Table 2)。その結果, P, I, R, Oいずれのカ テゴリーも，ポイントが一上がるごとにオッズ比は 1.33〜 1.51 倍程度有意に増加することが示され $(P<$ 0.0001), PROWESS study, PROGRESS study ともに PIRO scoreから割り出された予測在院死亡率と実際 の在院死亡率は, 非常に良く相関した。

前述までの研究が過去のデータベースからPIRO scoreを構築して予後との関係を調べたのに対して, Howellらは, 初めて前向き, コホート観察研究のデー

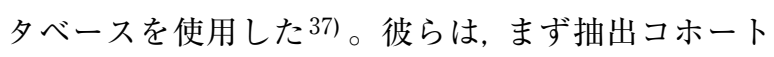
として 2003 年 12 月から 2004 年 9 月までにBeth Israel 
日集中医誌 J Jpn Soc Intensive Care Med Vol. 19 No. 4

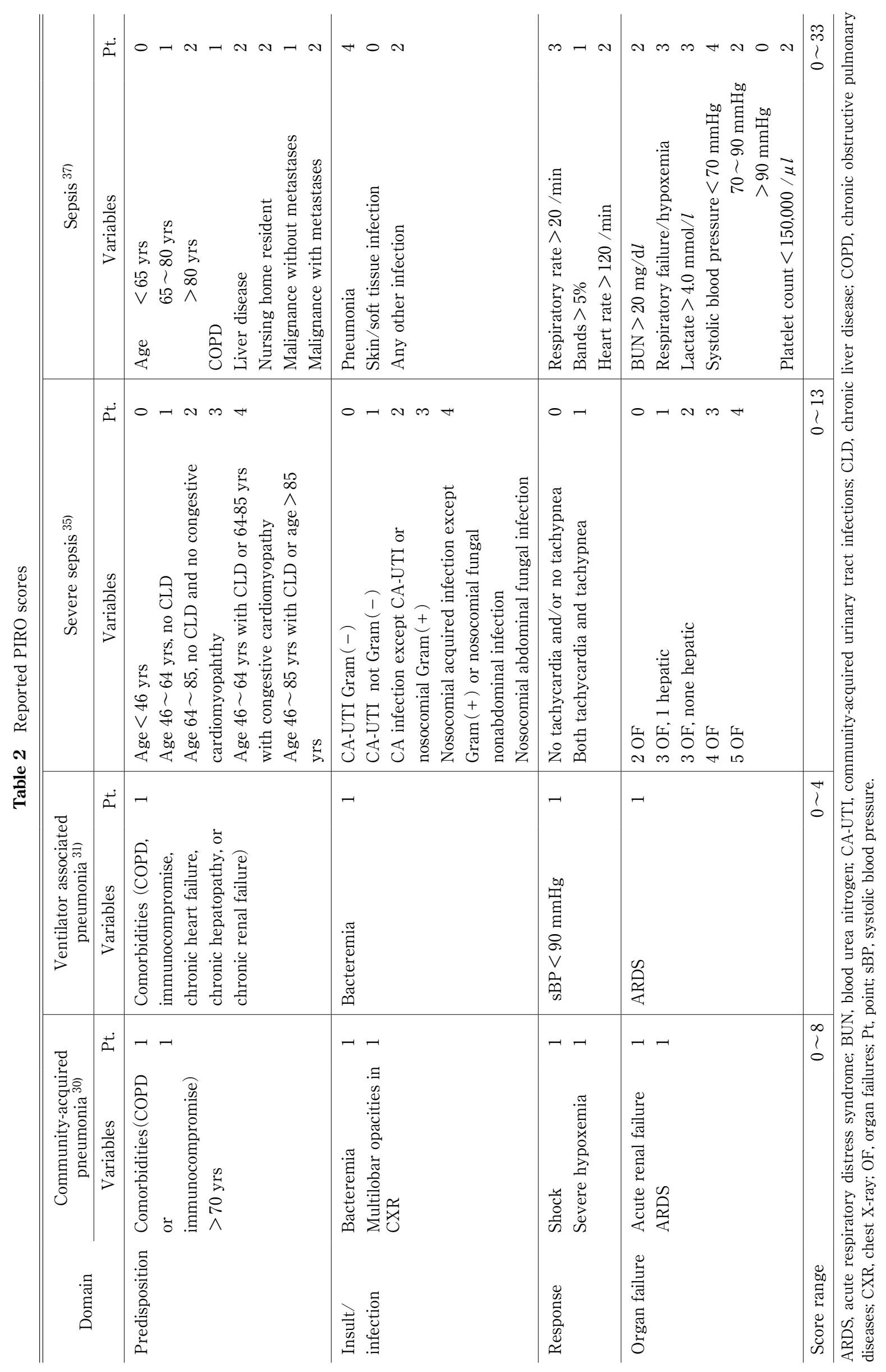


Deaconess Medical Centerを受診した2,132名の感染 症患者のデータベースから, PIRO scoreを構築した。 感染症ありと判断した基準は, (1)胸部写真上の浸潤影 や，尿中の白血球， CT 上の腹部感染巣など明らかな 感染巣の存在, (2)主治医の診療録記載内容, (3)救急部 門での抗菌薬の投与歴などである。PIROの各カテゴ リーに該当する候補項目を選定し, その項目が在院死 亡率に関与するか否かを, Fisher解析で調べた。その 結果, $P<0.1$ 示した各項目をロジスティック regression modelの候補とし, PIROの構成項目を決 定した。PIRO scoreの各項目のポイント数は, 多変量 ロジスティック解析の回帰係数 により決めた。

Predispositionに関する候補項目は, 年齢, 性別, 人 種, アルコール依存, 心筋梗塞例, 脳血管障害, 心不全, 結合織疾患, COPD, 認知症, 糖尿病, 尿留置カテーテ ル, 注射薬依存, 肝疾患, ナーシングホーム居住者, 末 梢血管疾患, 慢性腎疾患, 免疫不全, 悪性疾患, 転移性 がん, 30 日以内に死亡すると思われる致死的疾患, do not resuscitate (DNR) 症例などであった。Infection のカテゴリーの候補項目としては, 肺炎, 尿路感染, 胆道疾患, 腹腔内感染, カテーテル感染, 髄膜炎, 心膜 炎そのの他をリストアップした。Responseの候補は， 頻脈, 頻呼吸, 桿状核白血球増加, 体温上昇などで, organ dysfunctionの候補項目としては, 意識障害, 低 血圧, 血小板減少, クレアチニン上昇, 乳酸值上昇, 呼 吸数上昇または酸素化不良 (室内気吸入で $\mathrm{SpO}_{2}<$ $90 \%$ ，あるいは $\mathrm{O}_{2}>4 \mathrm{l} / \mathrm{min}$ 以上の投与で $\mathrm{SpO}_{2}<$ 95\%)などであった。

各項目に関するロジスティック回帰の結果から最終 的に構築されたPIRO scoreを Table 2 に示した。内 部検証コホートとして同病院を 2005 年 9 月から 2006 年9月まで受診した感染症患者 4,618 名, 扔よび外部 検証コホートとしてCarolinas Medical Centerを 2004 年7月から 2005 年 6 月までに受診した感染症患者 1,004名に関して, このPIRO scoreを適用して解析し た。その結果, 抽出コホートの ROC曲線下面積は 0.9 ともっとも優れた結果を示したが, 内部検証コホート, 外部検証コホートも各々 $0.85,0.83$ と良好な成績を示 した。

\section{PIRO scoreの問題点}

上述のように, PIRO scoreは, 市中肺炎やVAP, あ るいは敗血症で優れた予後予測能を示した。しかし， PIRO scoreにはいくつかの問題点がある。一つは, response と organ dysfunction との区別が明確でない
ことである。Responseの項で臨床項目の一つに挙げ られている「血圧」は, organ dysfunctionの項でも尿 量や意識レベルとともに臨床症状の筆頭に挙げられて いる。実際, Morenoらのstudy ${ }^{32) て ゙ は, ~ r e s p o n s e ~ と ~}$ dysfunctionを一つのカテゴリーとして解析を行って いる。このように, 研究者が自由にスコアを改変して 使用すると, スコアの普遍性が失われ, 無数の亜型が 生じる元となる。先の TNM分類は, アメリカ疾病管 理予防センター (Center for Disease Control and Prevention, CDC) や世界保健機構 (World Health Organization, WHO), 世界肺がん学会や国際産婦人 科連合などの国際機関と日本を含む15の国や地域の 代表が作成に参画しており，現在までに7版を重ねて いる17)。PIRO scoreに関しても研究者ごとにstaging を決定するのではなく, 国際的な合議によって決定さ れるべきだと考える。

また, TNM分類が各臟器の悪性腫瘍ごとに分類さ れているように, PIRO scoreも各感染症別にスコア化 されるべきである。現時点では, 市中肺炎, VAP, 重 症感染症などに限られているが, 感染症は他にも多数 あり，それをいかに分類してPIRO scoreにあてはめ るかという課題も今後, 解決していかねばならない。

また, TNM 分類が扱うがんでは, 解剖学的な広が りで重症度を分類する意義が, 過去半世紀以上不変で あったが, 敗血症の PIRO scoreでは, カテゴリー内の 項目が現在から未来に向けて著しく変化することが予 想される。例えばpredispositionとして, 現在は年齢 や合併症などが考えられているが, 将来的には遺伝子 解析 ${ }^{38)}$ の結果などが織り込まれるようになると考え られる。Infectionに関しても, 現在は感染病巣や起炎 菌による層別化がなされるが, いずれ菌の DNAや毒 素などが分類項目として組み込まれる可能性がある。 Response/organ dysfunctionにしても, 現在のSIRS PSOFA, MODSなどに変わって, さまざまなバイオ マーカーの指標などが取り上げられるかもしれ な(39) 45 )。

そもそも, PIRO scoreは敗血症の病態を層別化して 臨床研究の質を高める目的で提唱されたものである。 しかし, 予後予測のスコアとしての精度が吟味されて いるだけで, PIRO scoreを登録基準とした敗血症の臨 床研究は未だなされていないのが現状である46)。今 後, PIRO scoreによって重症度, 病態が均質化された 臨床研究がなされて, 初めてPIRO scoreの存在意義 が認められることになろう。

本稿の内容は, 第 38 回日本集中治療医学会学術集会 $(2011$ 
年, 横浜)にて, 講演した。

本稿の著者には規定されたCOIはない。

\section{文 献}

1) Vincent JL. Dear SIRS, I'm sorry to say that I don't like you... Crit Care Med 1997;25:372-4.

2) Dellinger RP, Levy MM, Carlet JM, et al; International Surviving Sepsis Campaign Guidelines Committee, American Association of Critical-Care Nurses, American College of Chest Physicians, et al. Surviving Sepsis Campaign: international guidelines for management of severe sepsis and septic shock: 2008. Crit Care Med 2008;36:296-327.

3) The Veterans Administration Systemic Sepsis Cooperative Study Group. Effect of high-dose glucocorticoid therapy on mortality in patients with clinical signs of systemic sepsis. N Engl J Med 1987;317:659-65.

4) Bone RC, Fisher CJ Jr, Clemmer TP, et al. A controlled clinical trial of high-dose methylprednisolone in the treatment of severe sepsis and septic shock. N Engl J Med 1987;317:653-8.

5) Warren BL, Eid A, Singer P, et al; KyberSept Trial Study Group. Caring for the critically ill patient. High-dose antithrombin III in severe sepsis: a randomized controlled trial. JAMA 2001;286:1869-78.

6) Bone RC, Balk RA, Fein AM, et al. A second large controlled clinical study of E5, a monoclonal antibody to endotoxin: results of a prospective, multicenter, randomized, controlled trial. The E5 Sepsis Study Group. Crit Care Med 1995;23:994-1006.

7) Hotchkiss RS, Karl IE. The pathophysiology and treatment of sepsis. N Engl J Med 2003;348:138-50.

8) Bone RC, Sibbald WJ, Sprung CL. The ACCP-SCCM consensus conference on sepsis and organ failure. Chest 1992;101:1481-3.

9) Bernard GR, Vincent JL, Laterre PF, et al; Recombinant human protein C Worldwide Evaluation in Severe Sepsis (PROWESS) study group. Efficacy and safety of recombinant human activated protein $\mathrm{C}$ for severe sepsis. $\mathrm{N}$ Engl J Med 2001;344:699-709.

10) Ely EW, Laterre PF, Angus DC, et al; PROWESS Investigators. Drotrecogin alfa (activated) administration across clinically important subgroups of patients with severe sepsis. Crit Care Med 2003;31:12-9.

11) Abraham E, Laterre PF, Garg R, et al; Administration of Drotrecogin Alfa (Activated) in Early Stage Severe Sepsis (ADDRESS) Study Group. Drotrecogin alfa (activated) for adults with severe sepsis and a low risk of death. N Engl J Med 2005;353:1332-41.

12) Vincent JL, Bernard GR, Beale R, et al. Drotrecogin alfa (activated) treatment in severe sepsis from the global open-label trial ENHANCE: further evidence for survival and safety and implications for early treatment. Crit Care Med 2005;33:2266-77.

13) Kanji S, Perreault MM, Chant C, et al. Evaluating the use of Drotrecogin alfa (activated) in adult severe sepsis: a Canadian multicenter observational study. Intensive Care Med 2007;33:517-23.

14) Eichacker $P Q$, Natanson $C$. Increasing evidence that the risks of rhAPC may outweigh its benefits. Intensive Care Med 2007;33:396-9.

15) Levy MM, Fink MP, Marshall JC, et al; SCCM/ESICM/
ACCP/ATS/SIS. 2001 SCCM/ESICM/ACCP/ATS/SIS International Sepsis Definitions Conference. Crit Care Med 2003;31:1250-6.

16) Marshall JC, Vincent JL, Fink MP, et al. Measures, markers, and mediators: toward a staging system for clinical sepsis. A report of the Fifth Toronto Sepsis Roundtable, Toronto, Ontario, Canada, October 25-26, 2000. Crit Care Med 2003;31:1560-7.

17) 序論. Sobin LH, Wittekind C, Gospodorowicz MK編, UICC 日本委員会 TNM 委員会訳. T N M 悪性腫瘍の分類 第7版. 東京：金原出版；2010。p. 1-19.

18) Angus DC, Burgner D, Wunderink R, et al. The PIRO concept: $\mathrm{P}$ is for predisposition. Crit Care 2003;7:248-51.

19) Vincent JL, Opal S, Torres A, et al. The PIRO concept: I is for infection. Crit Care 2003;7:252-5.

20) Roman-Marchant O, Orellana-Jimenez CE, De Backer D, et al. Septic shock of early or late onset: does it matter? Chest 2004;126:173-8.

21) Cohen J, Cristofaro P, Carlet J, et al. New method of classifying infections in critically ill patients. Crit Care Med 2004;32:1510-26.

22) Gerlach H, Dhainaut JF, Harbarth S, et al. The PIRO concept: R is for response. Crit Care 2003;7:256-9.

23) Vincent JL, Wendon J, Groeneveld J, et al. The PIRO concept: O is for organ dysfunction. Crit Care 2003;7: 260-4.

24) Marshall JC, Cook DJ, Christou NV, et al. Multiple organ dysfunction score: a reliable descriptor of a complex clinical outcome. Crit Care Med 1995;23:1638-52.

25) Jones AE, Trzeciak S, Kline JA. The Sequential Organ Failure Assessment score for predicting outcome in patients with severe sepsis and evidence of hypoperfusion at the time of emergency department presentation. Crit Care Med 2009;37:1649-54.

26) Vincent JL, Moreno R, Takala J, et al. The SOFA (Sepsisrelated Organ Failure Assessment) score to describe organ dysfunction/failure. On behalf of the Working Group on Sepsis-Related Problems of the European Society of Intensive Care Medicine. Intensive Care Med 1996;22:707-10.

27) Vincent JL, de Mendonça A, Cantraine F, et al. Use of the SOFA score to assess the incidence of organ dysfunction/failure in intensive care units: results of a multicenter, prospective study. Working group on "sepsis-related problems" of the European Society of Intensive Care Medicine. Crit Care Med 1998;26:1793-800.

28) Graciano AL, Balko JA, Rahn DS, et al. The Pediatric Multiple Organ Dysfunction Score (P-MODS): development and validation of an objective scale to measure the severity of multiple organ dysfunction in critically ill children. Crit Care Med 2005;33:1484-91.

29) Leteurtre S, Martinot A, Duhamel A, et al. Validation of the paediatric logistic organ dysfunction (PELOD) score: prospective, observational, multicentre study. Lancet 2003;362:192-7.

30) Rello J, Rodriguez A, Lisboa T, et al. PIRO score for community-acquired pneumonia: a new prediction rule for assessment of severity in intensive care unit patients with community-acquired pneumonia. Crit Care Med 2009;37:456-62.

31) Lisboa T, Diaz E, Sa-Borges M, et al. The ventilatorassociated pneumonia PIRO score: a tool for predicting ICU mortality and health-care resources use in ventilatorassociated pneumonia. Chest 2008;134:1208-16.

32) Moreno RP, Metnitz B, Adler L, et al; SAPS 3 
Investigators. Sepsis mortality prediction based on predisposition, infection and response. Intensive Care Med 2008;34:496-504.

33) Metnitz PG, Moreno RP, Almeida E, et al; SAPS 3 Investigators. SAPS 3--From evaluation of the patient to evaluation of the intensive care unit. Part 1: Objectives, methods and cohort description. Intensive Care Med 2005;31:1336-44.

34) Moreno RP, Metnitz PG, Almeida E, et al; SAPS 3 Investigators. SAPS 3--From evaluation of the patient to evaluation of the intensive care unit. Part 2: Development of a prognostic model for hospital mortality at ICU admission. Intensive Care Med 2005;31:1345-55.

35) Rubulotta F, Marshall JC, Ramsay G, et al. Predisposition, insult/infection, response, and organ dysfunction: A new model for staging severe sepsis. Crit Care Med 2009;37: 1329-35.

36) Beale R, Reinhart K, Brunkhorst FM, et al. Promoting Global Research Excellence in Severe Sepsis (PROGRESS): lessons from an international sepsis registry. Infection 2009;37:222-32.

37) Howell MD, Talmor D, Schuetz P, et al. Proof of principle: the predisposition, infection, response, organ failure sepsis staging system. Crit Care Med 2011;39:322-7.

38) Sutherland AM, Walley KR. Bench-to-bedside review: Association of genetic variation with sepsis. Crit Care 2009;13:210.
39) Hack CE, De Groot ER, Felt-Bersma RJ, et al. Increased plasma levels of interleukin-6 in sepsis. Blood 1989;74: 1704-10.

40) Claus RA, Bunck AC, Bockmeyer CL, et al. Role of increased sphingomyelinase activity in apoptosis and organ failure of patients with severe sepsis. FASEB J 2005;19:1719-21.

41) Liu SF, Malik AB. NF-kappa B activation as a pathological mechanism of septic shock and inflammation. Am J Physiol Lung Cell Mol Physiol 2006;290:L622-L645.

42) Kümpers P, Lukasz A, David S, et al. Excess circulating angiopoietin-2 is a strong predictor of mortality in critically ill medical patients. Crit Care 2008;12:R147.

43) Dahaba AA, Metzler H. Procalcitonin's role in the sepsis cascade. Is procalcitonin a sepsis marker or mediator? Minerva Anestesiol 2009;75:447-52.

44) David S, van Meurs M, Kümpers P. Does low angiopoietin-1 predict adverse outcome in sepsis? Crit Care 2010;14:180

45) Lin WC, Lin CF, Chen CL, et al. Prediction of outcome in patients with acute respiratory distress syndrome by bronchoalveolar lavage inflammatory mediators. Exp Biol Med (Maywood) 2010;235:57-65.

46) Soares M, Lisboa T, Salluh JI. Translating the PIRO staging system concept into clinical practice: where do we go from here? Crit Care Med 2011;39:408-9.

\title{
Abstract \\ Will clinical studies using the PIRO score lead to improvement of sepsis treatment?
}

\author{
Osamu Yamaguchi \\ Department of Anesthesia, Yokohama Municipal Citizen’s Hospital \\ 56 Okazawa-cho, Hodogaya-ku, Yokohama, Kanagawa 240-8555, Japan
}

One of the main goals of recent intensive care medicine is to overcome sepsis; however, no clinical trials about sepsis have proved the effectiveness of treatments. The cause seems to be due to the entry criteria of clinical studies about sepsis. Sepsis is defined as systemic inflammatory response syndrome (SIRS) caused by infection, but SIRS criteria is not specific and does not reflect severity and the pathophysiology of patients. Therefore, the PIRO score has been propounded, similar to the TNM classification in oncology. The four components of the PIRO score are predisposition, insult/infection, response, organ dysfunction and each category is scored to stratify the severity of sepsis. Staging contents of each category in the PIRO score have been proposed for severe sepsis, community acquired pneumonia, and nosocomial pneumonia. The PIRO score accurately predicted the prognosis of patients. A clinical study using this PIRO score as a precise characterization tool and staging system of patients is expected.

Key words: (1) severe sepsis, (2) septic shock, (3) systemic inflammatory response syndrome (SIRS), (4) PIRO score, (5) TNM classification

J Jpn Soc Intensive Care Med 2012;19:569-77. 